\title{
ENERGY AND EXERGY EVALUATION OF A 220MW THERMAL POWER PLANT
}

\author{
M. N. Eke' , D. C. Onyejekwe², O. C. Iloeje ${ }^{3}$, C. I. Ezekwe ${ }^{4}$ and P. U. Akpan ${ }^{5, *}$

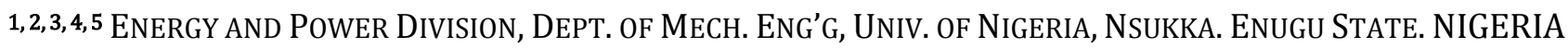 \\ 5 EPPEI SPEC.CENTRE In ENERGY EFFICIENCY, DEPT. OF MECH. ENGINEERING, UNIV. OF CAPE TOWN, SOUTH AFRICA \\ E-mail addresses. ${ }^{1}$ mkpamdi.eke@unn.edu.ng, ${ }^{2}$ david.onyejekwe@unn.edu.ng, \\ 3onwuamaeze.iloeje@unn.edu.ng, ${ }^{4} c o r n e l i u s . e z e k w e @ u n n . e d u . n g, 5$ patrick.akpan@unn.edu.ng
}

\begin{abstract}
A component based energy and exergy evaluation was performed on a 220MW thermal power plant in Nigeria. The component based exergy analysis examines and compares the energetic and exergetic performances of each component by identifying the deficiencies of each component. Design and operating data were obtained from Egbin power plant in Nigeria. The result of the analysis showed that the total exergy that was destroyed in the power plant was $400.015 \mathrm{MW}$. The major contributors to the exergy destruction in the power plant were the boiler (87\%), the three turbines (a combined total of 9\%) and the condenser (2\%). The effect of increasing the High Pressure turbine (HPT) inlet temperature at constant boiler pressure incresses the exergy efficiency of the component as well as the second law efficiency of the power plant, thus reducing the exergy destruction of the component. At the variation of environmental or dead state temperature, there were no appreciable changes in the values of exergy efficiency of the boiler/steam generator. The outcomes of this work provide the exergy consumption and distribution profiles of the thermal power plant, making it possible to adopt effective energy-saving measures.
\end{abstract}

\section{Keywords: Energy, Exergy, Efficiency, Sustainability, Power Plant and Boilers.}

\section{INTRODUCTION}

Thermal power plants are widely utilized throughout the world for electricity generation. They include steam power plants, gas turbine power plants, nuclear power plants, internal combustion engines etc. In recent years, global warming has been a major issue due to continuous growth of greenhouse gas emissions from different sources. Demirbas [1] reported that about $98 \%$ of $\mathrm{CO}_{2}$ emission results from fossil fuel combustion. The efficiency of power plants can be improved in order to minimize their environmental impacts [2]. The global energy supply and environmental situation requires an improved utilization of energy sources. Efforts are often expended to improve the efficiency and performance of existing plants through modifications to utilize the energy resources effectively and efficiently for electricity generation processes [2].

In the past, the energy-related engineering systems were designed, and their performance were evaluated primarily by using the energy balance deduced from first law of thermodynamics [2-3]. The first law of thermodynamics deals with the quantity of energy and asserts that energy cannot be created or destroyed [4].
In recent years the second law analysis, also known as exergy analysis, has drawn the interest of energy engineers and scientist [2-3].

Exergy is the amount of work obtained when a piece of matter is brought to a state of thermodynamic equilibrium with the common components of its surroundings by means of a reversible process [5]. Exergy analysis provides an effective technique for designing, evaluating, and optimizing the performance of a thermal system [2-8]. Exergy analysis represents the third step in the plant system analysis, following the mass and the energy balances. The aim of the exergy analysis is to identify the magnitudes and the locations of exergy losses, in order to improve the existing systems, processes or components, or to develop new processes or systems [9]. Exergy losses include the exergy flowing to the surroundings, whereas exergy destruction indicates the loss of exergy within the system boundary due to irreversibility [5].

There are a number of papers on energy and exergy analysis of thermal power plants. Erdem, et al. [10] carried out a comparative energy and exergy analysis for nine different coal fired power plants in Turkey. 
This analysis was done at design conditions. The authors were able to demonstrate the reasons why Power Plant CAN had the best performance of all the coal plants that were assessed. This was done using component exergy efficiency and component exergy destruction rate evaluation, Restrepo, et. al. [11] Performed an exergy and environmental analysis of a pulverised coal power plant. The analyses covered the coal delivery route, pre-burning processes and the power plant. They found out that the highest environmental impact occurred during the combustion process. Gupta and Kaushik [12] performed an energy and exergy analysis for different components of a proposed solar -thermal plant. Their report shows that the condenser and solar field contributes to the maximum energy loss, while the maximum exergy loss is experienced in the solar field. Vandani et. al. [13] performed an energy and exergy analysis of boiler blowdown heat recovery of a steam power plant. Their results show that an $0.72 \%$ increase in the net generation is achievable, and that the energy and exergy efficiencies of the plant also increased. Regulagadda, et. al [14] did a parametric study for a thermal plant using $n$ energy and exergy analysis. They assessed varying operating conditions. They found out that the irreversibilities in the boiler and turbine yield the highest exergy losses in the plant. Olaleye, et. al. [15] performed an exergy analysis of a supercritical power plant with post-combustion $\mathrm{CO}_{2}$ capture. The once-through boiler exhibited the highest exergy destruction of all the plants components. Their results also show that the rational efficiency of the system can be enhanced through improvement in turbine performance and the driving forces responsible for $\mathrm{CO}_{2}$ capture. Aljundi [16] studied the energy and exergy analysis of Al-Hussein power plant. The study analyzed the components of the plant separately, and identified the components with the highest energy and exergy losses. The report shows that the major components that make the largest energy destruction were the boiler system, turbine and the condenser. Their respective contributions were $77 \%, 13 \%$ and $9 \%$ respectively. Fu, et. al. [17] proposed an exergy based diagnostic method for effectively locating the components with performance degradation. The endogenous exergy destruction due to internal irreversibilities in the component itself was used. The tool was tested using a fault that was induced on a plant component. The tool was able to detect it, and also quantify the degradation. Zhao [18] performed an exergy analysis of the turbine cycle system of an ultrasupercritical power plant. They compared the results with that of a single reheat system. They found out that the exergy losses in the turbine of the double reheat system was less than that of the single reheat system, and the exergy loss in the condenser of the double reheat system is less than that of the single reheat system. Oko and Njoku [19] carried out an energy and exergy analysis of an integrated (IPP) gas, steam and organic rankine cycle thermal power plant. They reported a $1.95 \%$ exergy and $1.93 \%$ energy efficiency improvemnt of the IPP system. They also reported that the highest exergy destruction rate was experienced in the combustion chamber of the Combined cycle, and it was $59 \%$. In the ORC, the highest rate of exergy destruction occurred in the evaporator, $62 \%$.

The objective of this study is to evaluate the energy and exergy efficiencies and exergy destruction rate of the power plant system components, with a view to identifying systems that have potential for significant performance improvement.

\section{METHODOLOGY}

\subsection{Description of the Power Plant Investigated}

Egbin thermal plant is located at the suburb of Lagos State, Ijede area of Ikorodu and has a total of 1320 MW which consists of 6 units having individual capacity of $220 \mathrm{~W}$ [20]. They are systems with modern control equipment, single reheat; six stages regenerative feed heating. Natural gas is supplied to the plant directly from the Nigerian Gas Company (NGC) Egbin gas station which is annexed to the thermal plant. It is modelled as improved Rankine cycle with reheating and regenerative feedwater heating. The power plant consists of the steam generator which is the combination of the boiler, superheater and reheater. It consists of other components such as the turbine, the condenser, generator, pumps, feedwater heaters, drain cooler and deaerator. Additional components are usually added to enhance the cycle performance and improve efficiency. Natural gas is used as the primary energy source, which is ignited with air under pressure to start the boiler. The schematic diagram of the steam power plant is shown in Figure 1. The operating process parameters for the plant is presented in Appendix A.

\subsection{Equations and Analysis}

This study was based on the concept that for a system that undergoes a process under steady or quasi-steadystate conditions, the exergetic efficiency (second law efficiency, effectiveness or rational efficiency) is a valid measure of performance of the system from a thermodynamic point of view. The design and operating data of the power plant were obtained from the Efficiency Department of the thermal station. 


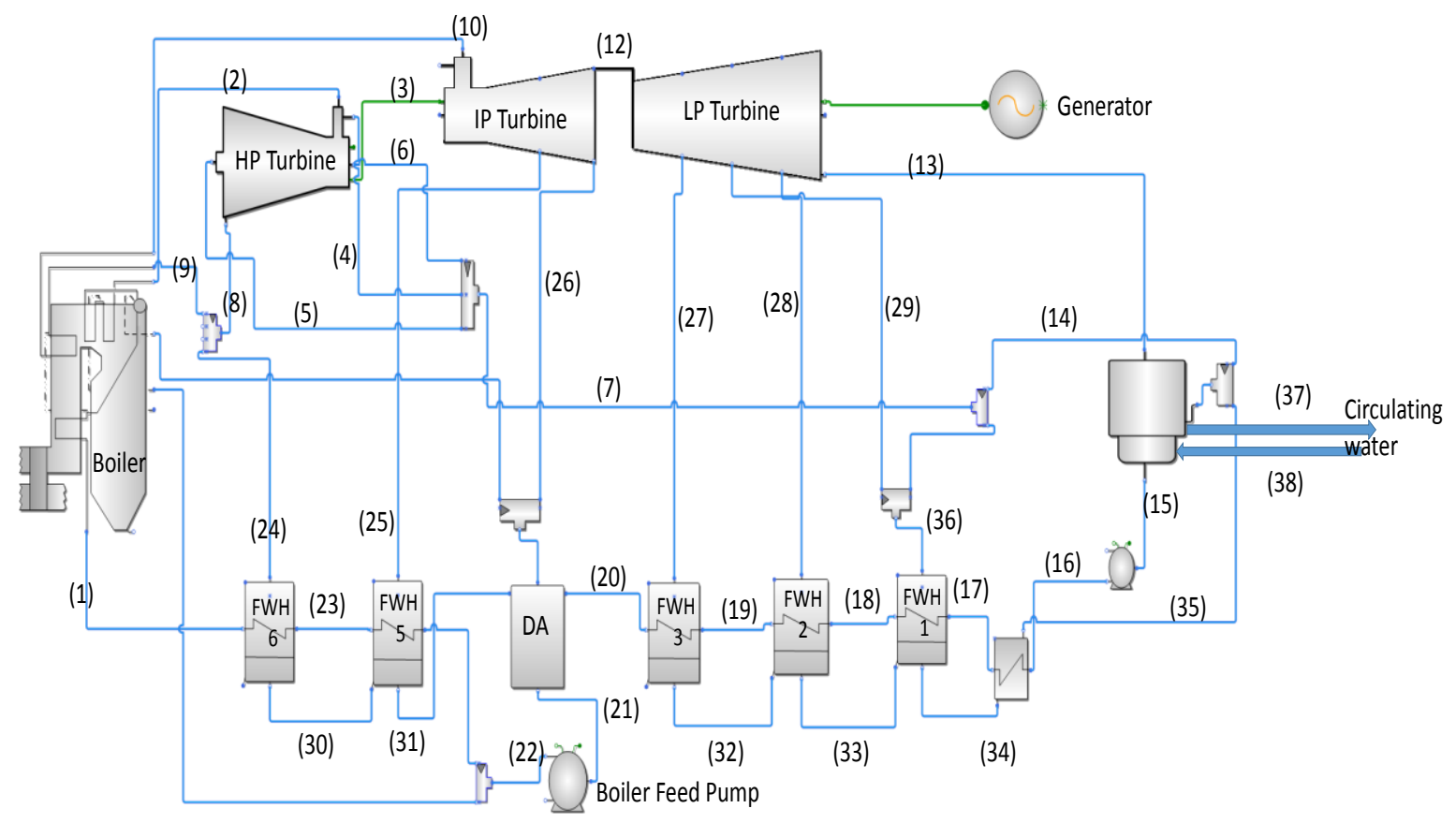

Figure 1: Schematic diagram of Egbin Steam Power Plant

The fundamental equations of mass, energy and exergy were formulated for the power plant components and resulting equations analysed using Scilab 5.5.2 version. For a typical component within the power plant (see Figure 2), there are energy and mass flows crossing the boundaries. Heat is transferred $\left(\dot{Q}_{c v}\right)$, work $\left(\dot{W}_{c v}\right)$ may also been done on/by the component.

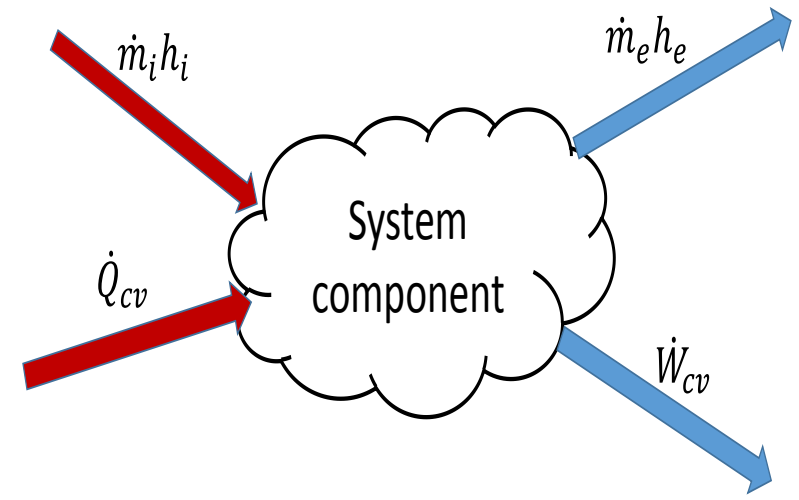

Figure 2: boundary of a typical component in the plant

The mass balance at steady state becomes:

$$
\sum \dot{m}_{i}=\sum \dot{m}_{e}
$$

From first law of thermodynamics, the energy balance at steady state neglecting potential and kinetic energy changes is given by [5]:

$$
\dot{Q}_{c v}+\sum_{i} \dot{m}_{i} h_{i}=\dot{W}_{c v}+\sum_{e} \dot{m}_{e} h_{e}
$$

Where $\dot{Q}_{c v}, \dot{W}_{c v}, h_{i}$ and $h_{e}$ are heat transfer rate, rate of energy transfer by work, enthalpy at inlet and enthalpy at exit respectively over the boundary of the control volume.

The energy or the first law efficiency $\eta_{1}$ of a system and/or system component is defined as the ratio of energy output to the energy input to a system/ or system component [5]:

$$
\eta_{1}=\frac{\text { Desired Output energy }}{\text { Input energy }}
$$

The exergy component of fluid in a steady flow is given by the sum of kinetic, potential, thermomechanical and chemical components (excluding nuclear effects, magnetism, electricity and surface tension) of the exergy [5]:

$$
E x_{\text {total }}=E x_{k}+E x_{p}+E x_{t h}+E x_{c h}
$$

where $E x_{\text {total }}=$ Total exergy of the flowing stream, $E x_{k}=$ kinetic exergy, $E x_{p}=$ potential exergy, $E x_{t h}=$ thermomechanical exergy, $E x_{c h}=$ chemical exergy. The potential and kinetic exergy components are evaluated relative to the environment. Since all the power plants components are considered to be at rest with respect to one another, these exergy components are neglected. Hence, the total exergy flow of the fluid stream is written thus:

$$
E x_{\text {total }}=E x_{t h}+E x_{c h}
$$

The computation of the steady state thermomechanical exergy for any component in the plant follows the model for an ideal gas depicted in Eq. 6a . This can also be simplified to Eq. $6 \mathrm{~b}[5,10]$.

$$
E x_{t h .}=\dot{m}\left(h-h_{0}\right)-\dot{m} T_{0}\left[s-s_{0}\right]
$$




$$
\begin{aligned}
E x_{\text {th. }}=\dot{m} C_{p}^{h}(T- & \left.T_{0}\right) \\
& -\dot{m} T_{0}\left[C_{P}^{S} \ln \left(\frac{T}{T_{0}}\right)-R \ln \left(\frac{P}{P_{0}}\right)\right]
\end{aligned}
$$

From Equation (6b), two forms of mean specific heat capacity may be defined as mean molar isobaric exergy capacity for evaluating enthalpy changes $C_{p}^{h}$ and mean molar isobaric exergy capacity for evaluating entropy changes $C_{p}^{s}$ as

$$
\begin{gathered}
C_{p}^{h}=\frac{1}{T-T_{0}} \int_{T_{0}}^{T} C_{p} d T \\
C_{p}^{S}=\frac{1}{\ln \left(\frac{T}{T_{0}}\right)} \int_{T_{0}}^{T} C_{p} \frac{d T}{T}
\end{gathered}
$$

$C_{p}$ in Equations (7) and (8) was obtained in a polynomial form as

$$
C_{p}=\frac{\bar{C}_{p}}{M}=A+B T+C T^{2}+D T^{3}
$$

where A, B, C and D are constants characteristics of gas obtained from selected ideal gas tables (see Appendix

B.) The computation of chemical exergy for a mixture of ideal gases is given as:

$$
E x_{c h}=\dot{m}\left(\sum_{i} y_{i} \overline{e x}_{i}^{c h}+R T_{0} \sum_{i} y_{i} \ln y_{i}\right)
$$

Where, $\overline{\mathrm{ex}}_{\mathrm{i}}^{\mathrm{ch}}$ is the chemical exergy of the constituents and $y_{i}$ is the mole fraction of the constituents.

The general exergy destruction rate that is derived from the exergy balance of a control volume of any of the plant component at steady state is given as [11]:

$$
\begin{aligned}
\dot{E} x_{D}=\sum \dot{E} x_{i n} & -\sum \dot{E} x_{o u t}+\sum\left(\dot{Q}\left(1-\frac{T_{o}}{T}\right)\right)_{i n} \\
& -\sum\left(\dot{Q}\left(1-\frac{T_{o}}{T}\right)\right)_{\text {out }} \pm \dot{W}
\end{aligned}
$$

The second law (exergy) efficiency of each component is defined as [5]:

$$
\eta_{2, i}=\frac{\text { Exergy Output }}{\text { Exergy Input }}
$$

where $\eta_{2, i}$ is the exergy or second law efficiency of the $i^{\text {th }}$ component.

The equations used in evaluating the exergy destruction rate $\left(E x_{D}\right)$, and the exergy efficiency $\left(\eta_{2, i}\right)$ of the main components of the plant are shown in Appendix C.

Fuel depletion ratio is an important parameter in exergy analysis. It is the ratio of the exergy destruction of $i^{\text {th }}$ component to the fuel exergy rate input of the plant and is given by the equation

$$
\varphi_{i}=\frac{E x_{D, i}}{E x_{f u e l}}
$$

where $\varphi_{\mathrm{i}}$ is the fuel depletion ratio and $\mathrm{Ex}_{\text {fuel }}$ exergy of fuel.

The cycle thermal efficiency of the plant is given as [5]:

$$
\eta_{\text {th }}=\frac{\left(\sum W_{T}-\sum W_{P}\right)}{Q_{\text {in }}} \times \frac{1}{\eta_{1, \text { boiler }}}
$$

The cycle exergy efficiency of the plant is given as [5]:

$$
\eta_{\text {2cycle }}=\frac{\left(\sum W_{T}-\sum W_{P}\right)}{E x_{f}} \times \frac{1}{\eta_{1, \text { boiler }}}
$$

\section{RESULT AND DISCUSSION}

The energy efficiencies for the system components are presented on Figure 3. The boiler feed water pump (BFP), the condenser effective pump (CEP), the condenser $(\mathrm{C})$, the intermediate pressure turbine (IPT) are operated slightly inefficiently. The boiler feed water pump was the least efficiently operated component when compared to its design efficiency. A deviation of $10 \%$ from the design condition was observed for it. This could be due a number of reasons ranging from wear and tears of its internal components. The implication of this is that there would be an increased consumption of power at the pump. The feed water heaters (H1, H2, H3, H5 and H6) are operating at their maximum efficiency level.

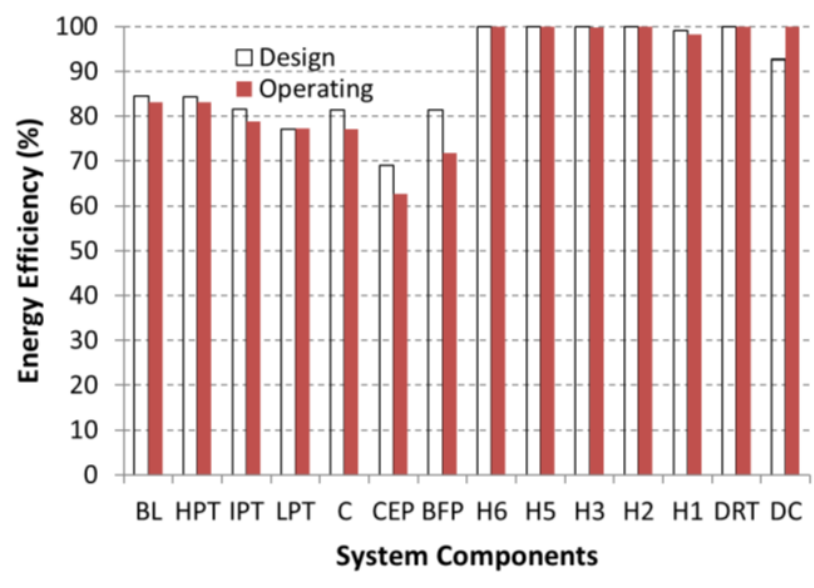

Figure 3: Energy efficiency for the system components

Figure 4 shows the exergy efficiencies for the system components. The boiler (BL) appears to have the least exergy efficiency (slightly above $40 \%$ ). This is due to irreversibility associated with combustion, mixing etc. The exergy efficiency for the condenser, condenser effective pump (CEP) are also very low. The exergy efficiency for the condenser is also low because a lot of heat is dumped outside the cycle. The implication of these observations is that, there is a lot of room for the utilisation of energy resources. 


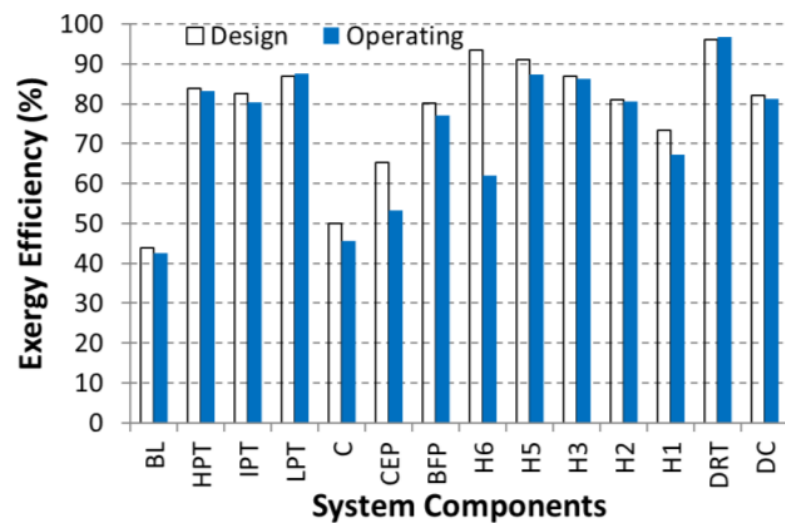

Figure 4: Exergy efficiency for the system components

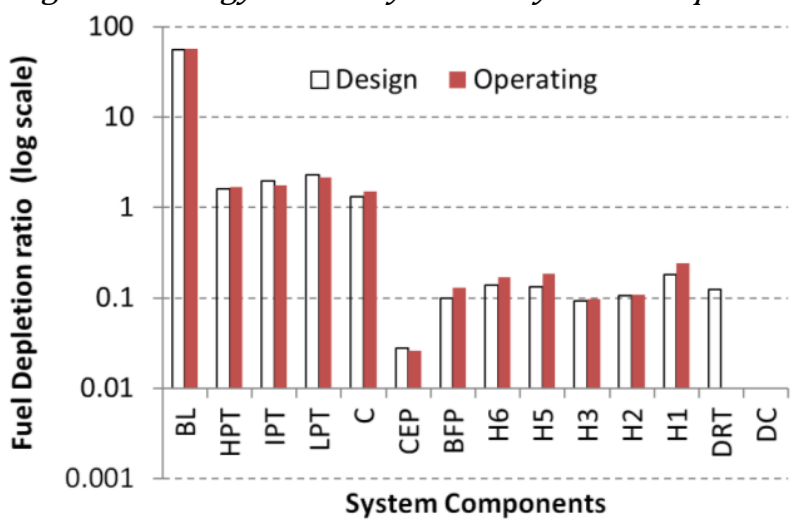

Figure 5: Fuel Depletion ratio for the System Components

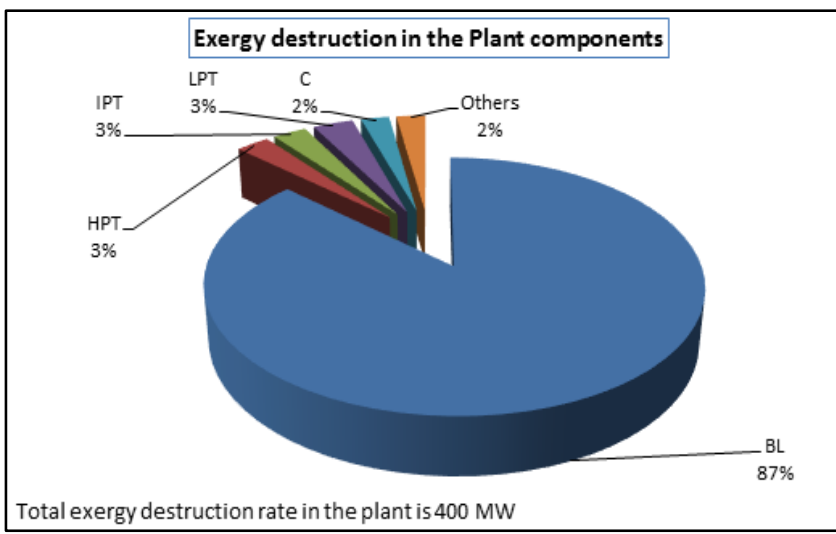

Figure 6: Percentage composition of exergy destruction of Components

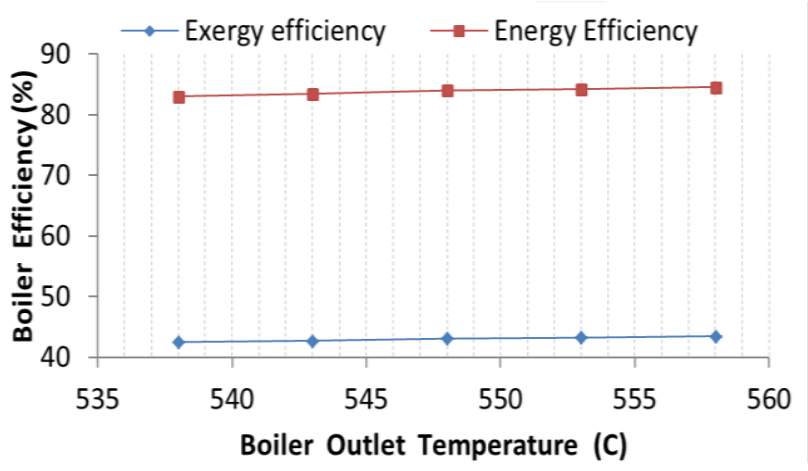

Figure 7: Effect of increase in boiler temperature at constant pressure on exergy efficiency.

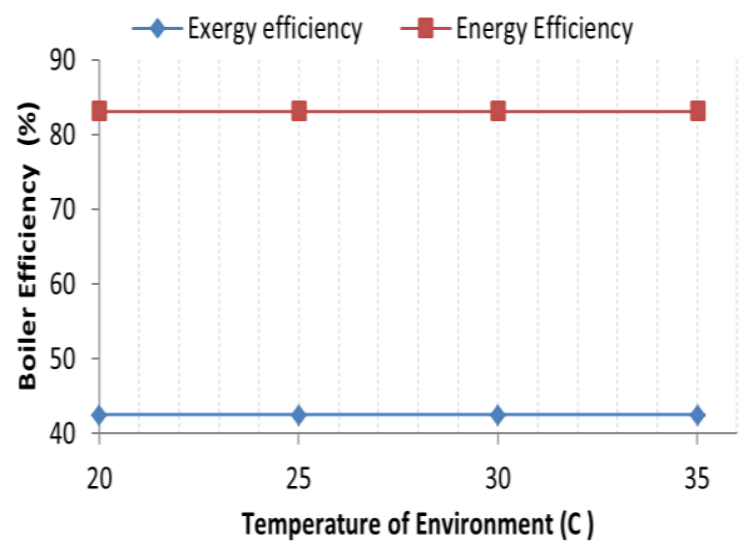

Figure 8: Effect of variation in ambient temperature on boiler exergy efficiency

Figure 5 shows the fuel depletion ratio at the various components. This ratio is an important parameter in exergy analysis because it gives an indication of the ratio of the exergy consumption of each component to the fuel exergy rate input of the plant. It is very high when compared with the one from the turbines (HPT, IPT and LPT) and the condenser. This indication as to why the exergy destruction at these components are high when compared to others.

In Figure 6, the total exergy destruction rate in the power plant was $400 \mathrm{MW}$. The major contributor to the exergy destruction in the power plant is the boiler (BL) with $87 \%$ (348 MW).

The other contributors are the high pressure turbine (HPT), the intermediate pressure turbine (IPT), low pressure turbine (LPT) and the condenser (C). The exergy destruction at each of these components are 3 $\%(12 \mathrm{MW}), 3 \%(12 \mathrm{MW}), 3 \%(12 \mathrm{MW})$ and $2 \%$ (8 MW) respectively of the total exergy that was destroyed at the power plant. The exergy loss at the remaining components constitutes $2 \%$ (8 MW) of the total exergy destroyed in the power plant.

The effect of increasing the boiler temperature on the exergy efficiency of the boiler is shown in Figure 7. It can be seen that the boiler exergy efficiency tends to increase by $0.05 \%$ per $1^{\circ} \mathrm{C}$ rise in the boiler temperature. However, it must be carefully noted that there is a limit to the maximum increment in the boiler temperature. This is due to the material properties of the boiler as well as the formation of thermal NOx.

The effect of increasing the environment (dead state) temperature on the boiler exergy efficiency is presented on Figure 8. There was no appreciable improvement in the values of exergy efficiency of the boiler/steam generator with changing dead state temperatures. A slight decrease can however be noted as the ambient temperature is increased. 


\section{CONCLUSION}

In this study, a component based energy and exergy evaluation of a 220 MW thermal power plant was performed. The result of the analysis showed that the total exergy that was destroyed in the power plant was 400 MW. The major contributors to the exergy destruction in the power plant were the boiler, the three turbines, and the condenser. Their contributions were 348MW (87\%), 36MW (9\%), 8MW (2\%) respectively. It is apparent from the analysis that the highest exergy destruction occurs in the boiler component. Its effect on the overall plant exergy efficiency is significant.

The effect of increasing the high Pressure turbine (HPT) inlet temperature at constant boiler pressure incresses the exergy efficiency of the component as well as the second law efficiency of the power plant, thus reducing the exergy destruction of the component. At the variation of environmental or dead state temperature, there were no appreciable changes in the values of exergy efficiency of the boiler/steam generator.

\section{REFERENCES}

[1] Demirbas A Carbon dioxide Emissions and Carbonations sensors Turkey, Energy Sources: Part A, 30: 70-78, 2008.

[2] Kanoglu, M., Dincer, I., and Rosen M. A. "Understanding energy and exergy efficiencies for improved energy management in power plants," Energy Policy, vol. 35, pp. 3967-3978, 2007.

[3] Kaushik, S. C., Reddy, V. S., and Tyagi, S. K. "Energy and exergy analyses of thermal power plants: A review," Renew. Sustain. Energy Rev., vol. 15, no. 4, pp. 1857-1872, 2011

[4] Cengel, Y. A. and Boles, M. A. Thermodynamics. An Engineering Approach $5^{\text {th }}$ Edition Mc-Graw Hill New Delhi, 2006.

[5] Moran, M. J. and Shapiro, H. N. Fundamentals of Engineering Thermodynamics, Fifth Edition, John Wiley and sons Inc, 2006.

[6] Bejan, A. Fundamental of Exergy Analysis, Entropy generation, minimization and generation of flow Architecture. Int. J of Energy Res. 26 (7) pp.1-43, 2002.

[7] Kopac, M and Zember R Exergy Analysis of steaminjected gas turbine, Int. J. Exergy 1(3), pp. 363374,2004

[8] Kopac, M and Kokturk, L. Determination of optimum speed of an internal combustion engine by exergy analysis. Int. J. Exergy 2 (1), pp. 40-54, 2005.
[9] Tekin, T and Bayramoglu, M. Exergy Analysis of Sugar Production process from sugar Beets, Int. J of Energy Research, 22, 591-601, 1998.

[10] Erdem. H., Akkaya. A., Cetin, B., Dagdas, A., Hakan, S., Sahin, B., Teke, I. Gungor, C. and S. Atas, "Comparative energetic and exergetic performance analyses for coal-fired thermal power plants in Turkey," Int. J. Therm. Sci., vol. 48, no. 11, pp. 2179-2186, 2009.

[11] Restrepo, Á., Miyake, R., Kleveston, F. and Bazzo, E. "Exergetic and environmental analysis of a pulverized coal power plant," Energy, vol. 45, pp. 195-202, 2012

[12] Gupta, M. K. and Kaushik, S. C. "Exergy analysis and investigation for various feed water heaters of direct steam generation solar - thermal power plant," Renew. Energy, vol. 35, no. 6, pp. 12281235, 2010

[13] Vandani, A. M. K., Bidi, M. and Ahmadi, F. "Exergy analysis and evolutionary optimization of boiler blowdown heat recovery in steam power plants," Energy Convers. Manag., vol. 106, pp. 1-9, 2015.

[14] Regulagadda, P., Dincer, I. and Naterer, G. F. "Exergy analysis of a thermal power plant with measured boiler and turbine losses," Appl. Therm. Eng., vol. 30, no. 8-9, pp. 970-976, 2010

[15] Olaleye, A. K., Wang, M. and Kelsall, G. "Steady state simulation and exergy analysis of supercritical coal-fired power plant with $\mathrm{CO} 2$ capture," Fuel, vol. 151, pp. 57-72, 2015.

[16] Aljundi, I. H. "Energy and exergy analysis of a steam power plant in Jordan," Appl. Therm. Eng., vol. 29, no. 2-3, pp. 324-328, 2009.

[17] Wang, P. Fu, N., Wang, L., Morosuk, T., Yang, Y. and Tsatsaronis, G. "Performance degradation diagnosis of thermal power plants: A method based on advanced exergy analysis," Energy Convers. Manag., vol. 130, pp. 219-229, 2016.

[18] Zhao, Z., Su, S., Si, N., Hu, S., Wang, Y., Xu, J., Jiang, L., Chen, G., and Xiang, J. Exergy analysis of the turbine system in a $1000 \mathrm{MW}$ double reheat ultrasupercritical power plant. Energy 119, 540-548, 2017.

[19] Oko, C. O. C. and Njoku, I. H. Performance analysis of an integrated gas-, steam- and organic fluidcycle thermal power plant. Energy 122431 - 443, 2017.

[20] Eke, M. N. "Long term Energy Performance analysis of Egbin Thermal Power Plant, Nigeria" Nigerian Journal of Technology, 33 (1), 2014. 97103, 2013.

[21] Elliot J. R. and Lita, C. T. Introductory chemical Engineering Thermodynamics: in Perry's chemical Engineering Handbook, $6^{\text {th }}$ edition and Lang's Hand. Printice-Hall, 1999. 


\section{NOMENCLATURE}

\begin{tabular}{|c|c|c|}
\hline Symbols & Meaning & Unit \\
\hline $\mathrm{C}_{\mathrm{p}}$ & $\begin{array}{l}\text { Specific heat at constant } \\
\text { pressure }\end{array}$ & $\mathrm{kJ} / \mathrm{kgK}$ \\
\hline$\dot{C}_{p}$ & $\begin{array}{l}\text { Molar specific heat at } \\
\text { constant pressure }\end{array}$ & {$[\mathrm{kmol} / \mathrm{KgK}]$} \\
\hline$E x_{\text {total }}$ & Total Exergy & $\mathrm{kW}$ \\
\hline$E x_{t h}$ & Thermochemical Exergy & $\mathrm{kW}$ \\
\hline$E x_{c h}$ & Chemical Exergy & $\mathrm{kW}$ \\
\hline$\dot{E} x_{f}$ & Fuel Exergy rate & $\mathrm{kW}$ \\
\hline$\dot{E} x_{D}$ & Exergy destruction rate & $\mathrm{kW}$ \\
\hline $\mathrm{H}$ & Specific enthalpy & $\mathrm{kJ} / \mathrm{kg}$ \\
\hline $\mathrm{H}$ & Specific enthalpy & $\mathrm{Kmol} / \mathrm{k}$ \\
\hline$\dot{m}$ & Mass flow rate & $\mathrm{kg} / \mathrm{s}$ \\
\hline M & Molar mass of gas & $\mathrm{Kg} / \mathrm{kmol}$ \\
\hline$\dot{Q}$ & Heat transfer rate & $\mathrm{kW}$ \\
\hline $\mathrm{R}$ & Specific gas constant & $\mathrm{kJ} / \mathrm{kgK}$ \\
\hline S & Specific entropy & $\mathrm{kJ} / \mathrm{kgK}$ \\
\hline $\mathrm{S}_{0}$ & $\begin{array}{l}\text { Entropy at reference } \\
\text { temperature }\end{array}$ & $\mathrm{kJ} / \mathrm{kgK}$ \\
\hline$\dot{W}$ & Work rate & $\mathrm{kW}$ \\
\hline WT & Turbine work & $\mathrm{kW}$ \\
\hline WP & Pump work & $\mathrm{kW}$ \\
\hline $\mathrm{y}_{\mathrm{i}}$ & $\begin{array}{l}\text { Mole fraction } \\
\text { constituent gas }\end{array}$ & - \\
\hline
\end{tabular}

$\eta_{1}$ - Energy efficiency [\%]

$\eta_{2}$ - Exergy efficiency [\%]

$\varphi_{i}$ - Fuel depletion ratio of $\mathrm{i}^{\text {th }}$ component. [\%]

Subscripts

$c v$ - Control volume []

$i$ - Inlet []

$e$ - Exit []

\section{ABBREVIATIONS}

BL - Boiler

HPT - High Pressure Turbine

IPT - Intermediate Pressure Turbine

LPT - Low Pressure Turbine

C - Condenser

CEP - Condenser effective Pump

BFP - Boiler Feed Pump

$\mathrm{HPH}$ - High Pressure heater

LPH - Low Pressure heater

$\mathrm{H}$ - Heater

DRT - Deaerator

DC - Drain cooler

\section{ACKNOWLEDGEMENTS}

The authors are grateful to the staff of Energy efficiency Department at Egbin Power Plant for their support in making data available for this research.

Greek Symbols

APPENDIX A: PROCESS PARAMETER

\begin{tabular}{|c|c|c|c|c|c|c|}
\hline Node & $\begin{array}{l}\text { Pressure } \\
\quad(\mathrm{Pa})\end{array}$ & $\begin{array}{l}\text { Temperature } \\
\text { (C) }\end{array}$ & Quality & $\begin{array}{l}\text { Enthalpy } \\
(\mathrm{kJ} / \mathrm{kg})\end{array}$ & $\begin{array}{l}\text { Entropy } \\
(\mathrm{kJ} / \mathrm{kgK})\end{array}$ & $\begin{array}{c}\text { Mass flow rate } \\
{[\mathrm{Kg} / \mathrm{s}]}\end{array}$ \\
\hline 1 & 12516.5 & 237.7 & 0.00 & 1026 & 2.66 & 607917.36 \\
\hline 2 & 12516.5 & 539.06 & 1.00 & 3446.40 & 6.59 & 627365.70 \\
\hline 3 & 3319 & 459.80 & 1.00 & 3362.00 & 7.10 & 10759.32 \\
\hline 4 & 12516.5 & 539.06 & 1.00 & 3446.40 & 6.59 & 375.92 \\
\hline 5 & 12516.5 & 539.06 & 1.00 & 3446.40 & 6.59 & 1208 \\
\hline 6 & 3319 & 350.90 & 1.00 & 3109.70 & 6.69 & 1706.43 \\
\hline 7 & 3319 & 350.90 & 1.00 & 3109.70 & 6.69 & 3563.44 \\
\hline 8 & 3319 & 353.70 & 1.00 & 3116.50 & 6.70 & 610928.72 \\
\hline 9 & 3265.76 & 353.22 & 1.00 & 3116.50 & 6.71 & 561626.77 \\
\hline 10 & 3084.20 & 539.06 & 1.00 & 3543.70 & 7.32 & 561626.77 \\
\hline 11 & 695.88 & 329.08 & 1.00 & 3121.10 & 7.40 & 1046.87 \\
\hline 12 & 695.88 & 329.08 & 1.00 & 3121.10 & 7.40 & 520403.37 \\
\hline 13 & 9.20 & 44.21 & 0.92 & 2580.90 & 8.178 & 444788.76 \\
\hline 14 & 9.20 & 43.96 & 0.00 & 184.07 & 0.625 & 444788.76 \\
\hline 15 & 9.20 & 43.96 & 0.00 & 184.07 & 0.625 & 524063.86 \\
\hline 16 & 1282.85 & 44.20 & 0.00 & 186.19 & 0.628 & 524063.86 \\
\hline 17 & 1282.85 & 49.7 & 0.00 & 209.2 & 0.70 & 524063.86 \\
\hline 18 & 1282.85 & 86.53 & 0.00 & 363.3 & 1.15 & 524063.86 \\
\hline 19 & 1282.85 & 110.1 & 0.00 & 462.6 & 1.42 & 524063.86 \\
\hline 20 & 1282.85 & 134.30 & 0.00 & 565.4 & 1.68 & 524063.86 \\
\hline
\end{tabular}




\begin{tabular}{|c|c|c|c|c|c|c|}
\hline Node & $\begin{array}{l}\text { Pressure } \\
\quad(\mathrm{Pa})\end{array}$ & $\begin{array}{l}\text { Temperature } \\
\text { (C) }\end{array}$ & Quality & $\begin{array}{l}\text { Enthalpy } \\
(\mathrm{kJ} / \mathrm{kg})\end{array}$ & $\begin{array}{l}\text { Entropy } \\
(\mathrm{kJ} / \mathrm{kgK})\end{array}$ & $\begin{array}{c}\text { Mass flow rate } \\
{[\mathrm{Kg} / \mathrm{s}]}\end{array}$ \\
\hline 21 & 667.04 & 163 & 0.00 & 688.7 & 1.97 & 627365.70 \\
\hline 22 & 13768.44 & 165.5 & 0.00 & 707.10 & 1.98 & 627365.70 \\
\hline $22 \mathrm{~b}$ & 0 & 0 & 0.00 & 0 & 0 & 19448.34 \\
\hline 23 & 13768.44 & 196.6 & 0.00 & 842.6 & 2.28 & 607917.36 \\
\hline 24 & 3212.98 & 352.70 & 1.00 & 3116.42 & 6.715 & 48739.89 \\
\hline 25 & 1541.09 & 435.80 & 1.00 & 3332.80 & 7.40 & 29002.41 \\
\hline $25^{1}$ & 1448.08 & 435.22 & 1.00 & 3332.80 & 7.40 & 29002.41 \\
\hline 26 & 695.88 & 329.80 & 1.00 & 121.10 & 7.41 & 25450.03 \\
\hline $26^{1}$ & 667.04 & 329.50 & 1.00 & 3121.10 & 7.41 & 25450.03 \\
\hline 27 & 366.34 & 260.80 & 1.00 & 2986.91 & 7.42 & 21677.92 \\
\hline 271 & 344.24 & 260.45 & 1.00 & 2986.91 & 7.49 & 21677.92 \\
\hline 28 & 174.65 & 188.10 & 1.00 & 2847.39 & 7.52 & 20295.73 \\
\hline $28^{1}$ & 164.11 & 187.82 & 1.00 & 2847.39 & 7.52 & 20295.73 \\
\hline 29 & 76.60 & 112.50 & 1.00 & 2703.78 & 7.52 & 33649.28 \\
\hline 291 & 71.55 & 112.25 & 1.00 & 2703.77 & 7.52 & 33649.28 \\
\hline 30 & 3212.98 & 202.7 & 0.00 & 865.2 & 2.35 & 48739.89 \\
\hline 31 & 1448.08 & 171.50 & 0.00 & 726.2 & 2.06 & 77742.29 \\
\hline 32 & 344.24 & 118.1 & 0.00 & 495.8 & 1.51 & 21677.92 \\
\hline 33 & 164.11 & 94.53 & 0.00 & 396.1 & 1.25 & 41973.65 \\
\hline 34 & 1382.85 & 90.53 & 0.00 & 379.2 & 1.20 & 76824.55 \\
\hline 35 & 71.55 & 52.20 & 0.00 & 218.58 & 0.732 & 76824.55 \\
\hline 36 & 695.88 & 329.80 & 1.00 & 3121.13 & 7.406 & 1201.62 \\
\hline 37 & 100 & 30.42 & 0.00 & 127.51 & 0.40 & 32660000 \\
\hline 38 & 100 & 36.73 & 0.00 & 153.91 & 0.50 & 32660000 \\
\hline
\end{tabular}

\section{APPENDIX B: HEAT CAPACITIES OF GASES AT VARYING TEMPERATURES}

For more accurate calculation, use the polynomial expression $\overline{\mathrm{C}}_{\mathrm{p}}=\mathrm{A}+\mathrm{BT}+\mathrm{CT}^{2}+\mathrm{DT}^{3}$, where $\overline{\mathrm{C}}_{\mathrm{p}}$ is in $\mathrm{KJ} / \mathrm{KmolK}$

\begin{tabular}{c|c|c|c|c}
\hline Compound & A & B & C & D \\
\hline N-Butane & 9.487 & 0.3313 & $-1.108 \times 10^{-4}$ & $-2.822 \times 10^{-9}$ \\
Ethane(g) & 5.409 & 0.1781 & $-6.94 \times 10^{-5}$ & $8.71 \times 10^{-9}$ \\
N-Heptane & -5.146 & 0.6762 & $-3.651 \times 10^{-4}$ & $7.658 \times 10^{-8}$ \\
N-Hexane & -4.413 & 0.528 & $-3.119 \times 10^{-4}$ & $6.498 \times 10^{-8}$ \\
I-Butane & $-1.390-9.525$ & 0.3847 & $-1.846 \times 10^{-4}$ & $2.895 \times 10^{-8}$ \\
I-Pentane & 19.25 & 0.5066 & $-2.729 \times 10^{-4}$ & $5.723 \times 10^{-8}$ \\
Methane & 31.15 & 0.05213 & $1.197 \times 10^{-5}$ & $-1.132 \times 10^{-8}$ \\
Nitrogen & -6.096 & $-1.357 \times 10^{-2}$ & $2.680 \times 10^{-5}$ & $-1.168 \times 10^{-8}$ \\
N-Octane(g) & -3.626 & 0.7712 & $-4.195 \times 10^{-4}$ & $8.855 \times 10^{-8}$ \\
N-Pentane & -4.224 & 0.4873 & $-2.58 \times 10^{-4}$ & $5.305 \times 10^{-8}$ \\
N-Propane & -24.35 & 0.3663 & $-1.586 \times 10^{-4}$ & $3.215 \times 10^{-8}$ \\
Toluene & -29.27 & 0.5125 & $-2.765 \times 10^{-4}$ & $4.991 \times 10^{-8}$ \\
M-Xylene & 28.11 & 0.6297 & $-3.747 \times 10^{-4}$ & $8.478 \times 10^{-8}$ \\
Air & & $0.1967 \times 10^{-2}$ & $0.4802 \times 10^{-5}$ & $-1.966 \times 10^{-9}$ \\
\hline
\end{tabular}

Source: Compiled from Elliot and Lita [21]. 
APPENDIX C: EXERGY DESTRUCTION AND EXERGY EFFICIENCY EQUATIONS FOR THE VARIOUS PLANT COMPONENTS

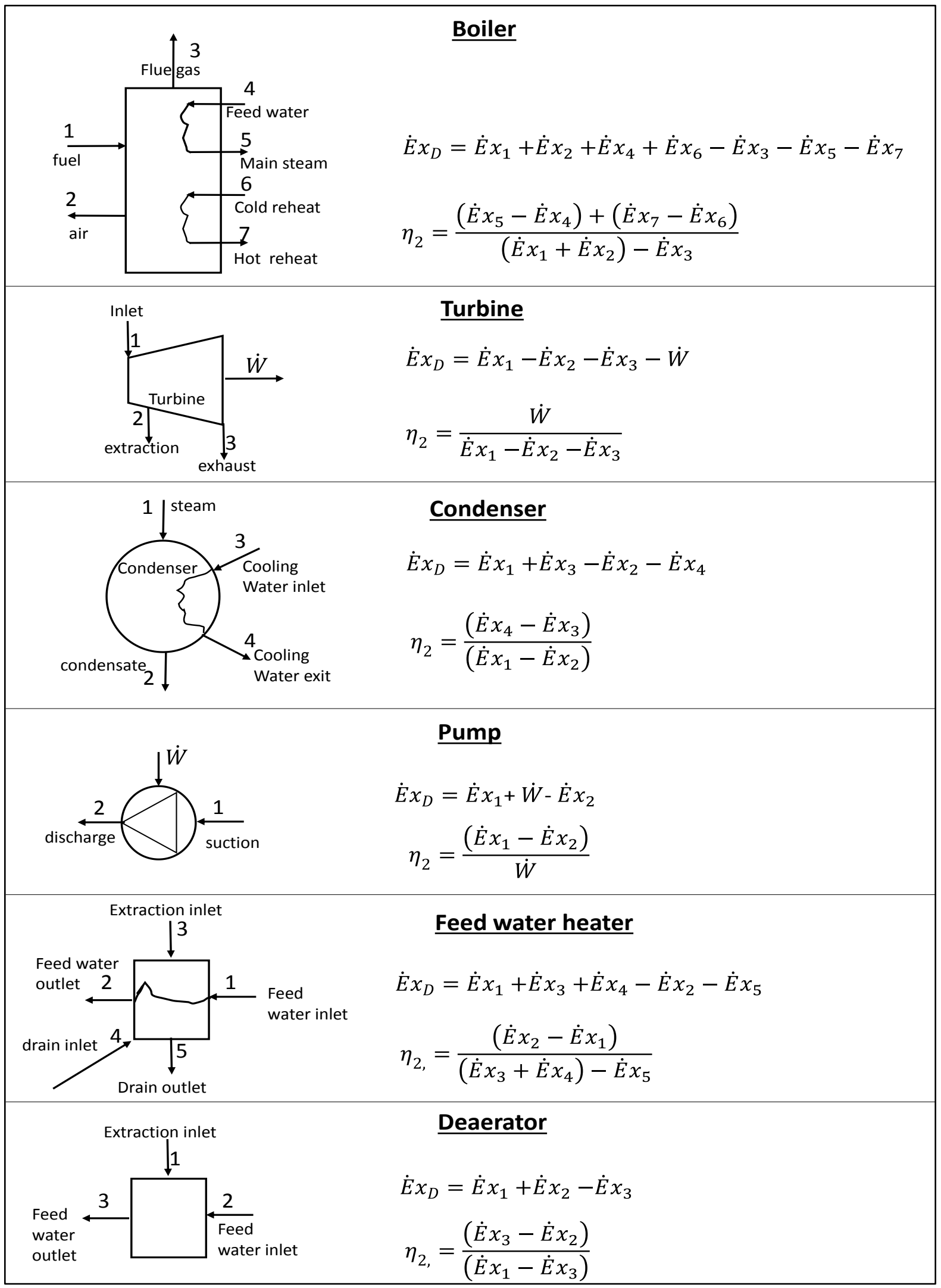

